\title{
The Role of Health Promotion in Management Development. A Systematic Review of Training Concepts in an Organizational Context
}

http://doi.org/10.21272/bel.5(1).89-97.2021

Michael Hans Gino Kraft, ORCID: https://orcid.org/0000-0002-2133-1111

PhD \& Senior expert for Business Strategy \& Development, Hamburg, Germany

\begin{abstract}
Economic success often depends on the health of managers and employees in the company. In this context, health promotion programs are becoming increasingly important to ensure the quality of work and for reducing absenteeism. Although academic interest in the study of individual health in organizations is growing, there is still a need for research to fully understand its potential in the area of management development as well. Under this premise, this article summarizes the arguments and counter-arguments within the scientific discussion on health-promoting aspects in the context of management development. The purpose of this work is to systematically deepen the understanding of corporate health promotion by reviewing the relevance of healthrelated aspects in management training concepts. Given this evidence, this work contains a systematic literature review about management training programs and empirical contributions. The review took place between November 2020 and February 2021 by using different scientometric databases such as Econbiz, Scopus and Web of Science. Among 56 identified publications, 20 studies address such management training concepts in the context of health issues. The paper provides initial evidence of differing understandings of health promotion in management development and identifies difficulties in implementing and prioritizing health promotion in training programs on the management level. Even though health-promoting topics are becoming increasingly important, self-leadership aspects still play a subordinate role in development programs. The study proved that despite the economic importance of the individual health of employees and managers, health promotion is still seen as a self-reflective task. Practitioners are therefore invited to test the potential of healthpromoting elements in management training and to implement them in organizational reality.
\end{abstract}

Keywords: Health Promotion, Management Development, Organizational Health, Systematic Literature Review, Self-Leadership, Training.

JEL Classification: M12, M50, M53.

Cite as: Kraft, M.H.G. (2021). The Role of Health Promotion in Management Development. A Systematic Review of Training Concepts in an Organizational Context. Business Ethics and Leadership, 5(1), 89-97. http://doi.org/10.21272/bel.5(1).89-97.2021.

Received: 20 January $2021 \quad$ Accepted: 14 March $2021 \quad$ Published: 30 March 2021

Copyright: (C) 2021 by the author. Licensee Sumy State University, Ukraine. This article is an open access article distributed under the terms and conditions of the Creative Commons Attribution (CC BY) license (https://creativecommons.org/licenses/by/4.0/).

\section{Introduction}

Health promotion programs are increasingly implemented in corporate practice (Busch et al., 2017). In addition to ethical considerations, economic reasons play a central role (Ogbonnaya \& Babalola, 2019). Relying on empirical studies, workplace health promotion increases the quality of work and reduces the number of days of absence due to illness (Freire \& Bettencourt, 2020). According to the concept of salutogenesis developed by the U.S. medical sociologist Aaron Antonovsky, occupational health depends on two fundamental factors. These are, on the one hand, the quantitative and qualitative issues on people in their working lives in connection with their resource potential (Esslinger et al., 2010). From this perspective, health is not only influenced by preventive measures for a healthy lifestyle, but also by the design of working conditions, as well as by management methods and the working atmosphere (Rattrie \& Kittler, 2020). According to James \& Zoller (2018), companies that are committed to health-oriented management often emphasize issues such as nutrition and the work-life balance of their employees.

Against this background, managers play a central role in health-oriented work design. Thus, executives have the responsibility to reduce health issues in the company and to set up health-promoting measures and offers. 
To enable managers to implement such health promotion, many publications state that health-related content should be integrated as part of management training (Ayeleke et al., 2019). In such management training courses, executives not only receive professional information on health topics but are also educated on how health-promoting management, which can be strategically and operationally conceived (Einarsen et al., 2019).

Under this premise, this paper uses a systematic literature review to discuss different management training that relates to health, nutrition, and work-life balance. With this in mind, the central question that motivates this paper is: Which relevance do health-related aspects have in management development? And what are the effects of health-oriented management programs? To date, a literature-based review of this question has not been explored. Only a relatively small number of recent articles such as Car et al. (2018) and Tranfield et al. (2003) are concerned with organizational health in a management context. However, these articles focused primarily on the impact of health-enhancing organizational practices. Additional work in this field is therefore needed to understand the effectiveness of training approaches and to be able to explore any potential for human resource development. In this context, the main interest of this study is to investigate the perspectives of management development in the field of health promotion and to contribute to organizational health.

\section{Theoretical Background}

Health Issues at the Workplace. In general, employees of companies can suffer from all mental and physical illnesses (Freire \& Bettencourt, 2020). Nevertheless, there are specific occupational health risks that are related to the respective workplace. If these health risks lead to illnesses, they are often referred to as occupational diseases. Occupational diseases are related to the work environment, work processes and work materials. Occupational accidents can also be referred to as occupational diseases. A problem for employees is that they often exceed their physical and mental capacity at their workplace, which results in health problems (Rattrie \& Kittler, 2020).

Stress represents a central health issue in everyday working life. Stress can be regarded as a multi-layered health problem and is defined by many researchers as physical, chemical, biological, social and psychological demands, which leads to an activation of the organism. This tendency leads to (psycho-physiological or psychosomatic) disorders (Hopkins et al., 2018). When stress occurs, there is an increase in heart rate and respiratory rate, as well as an increase in blood sugar levels. In the long term, stress is associated with a weakening of the immune system. At the same time, stress lowers memory and learning performance and promotes the occurrence of cardiovascular diseases. Stress also increases the likelihood of mental illnesses such as burnout and depression Freire \& Bettencourt, 2020). With this in mind managers as well as employees are also exposed to health stress at the workplace. From an executive perspective, managing employees is not only a responsible task but also an exhausting one. Many executives show such a high level of commitment in their professional activities that they only realize at a late stage when their own needs can no longer be satisfied, and certain areas of their lives become unbalanced. Accordingly, managers are faced with the task of self-and stress management (Johnson et al., 2020).

Health Promotion Management. Health-oriented management is often expressed in institutionalized occupational health conception. Such health management is not only the responsibility of managers but also involves other company stakeholders (Dunsch et al., 2017). For example, the HR departments, the employee representatives or works council and all employees are often involved in the conception and implementation of a health management system. According to definition, occupational health management encompasses the totality of interrelated measures that serve to maintain and promote the physical and mental performance (ability) and motivation (willingness) of employees and ensure the necessary conditions for this. In the recent past, companies have increasingly turned to the potential of health-promoting management in leadership, also known as health leadership (Lee \& Sozen, 2016). In this context, companies and their managers strive to have a positive effect on the health of their employees and their physical well-being. Health-promoting management focuses on promoting employees' willingness and ability to perform (James \& Zoller, 2018). The increased importance of health-oriented management is reflected not only in the fact that companies are creating and implementing concepts in this regard, but also in a considerable increase in management seminars in which a health-promoting management style is taught (Lee \& Sozen, 2016).

Figure 1 shows the different levels of health-promoting management. The starting point is self-leadership on the part of the manager. In doing so, the manager must be aware of the importance of the health issue. Moreover, managers must be mindful of health issues and implement health-promoting behaviors. These principles are also implemented in the management of employees, whereby the aim is to ensure that employees adopt a health-conscious self-leadership approach. 


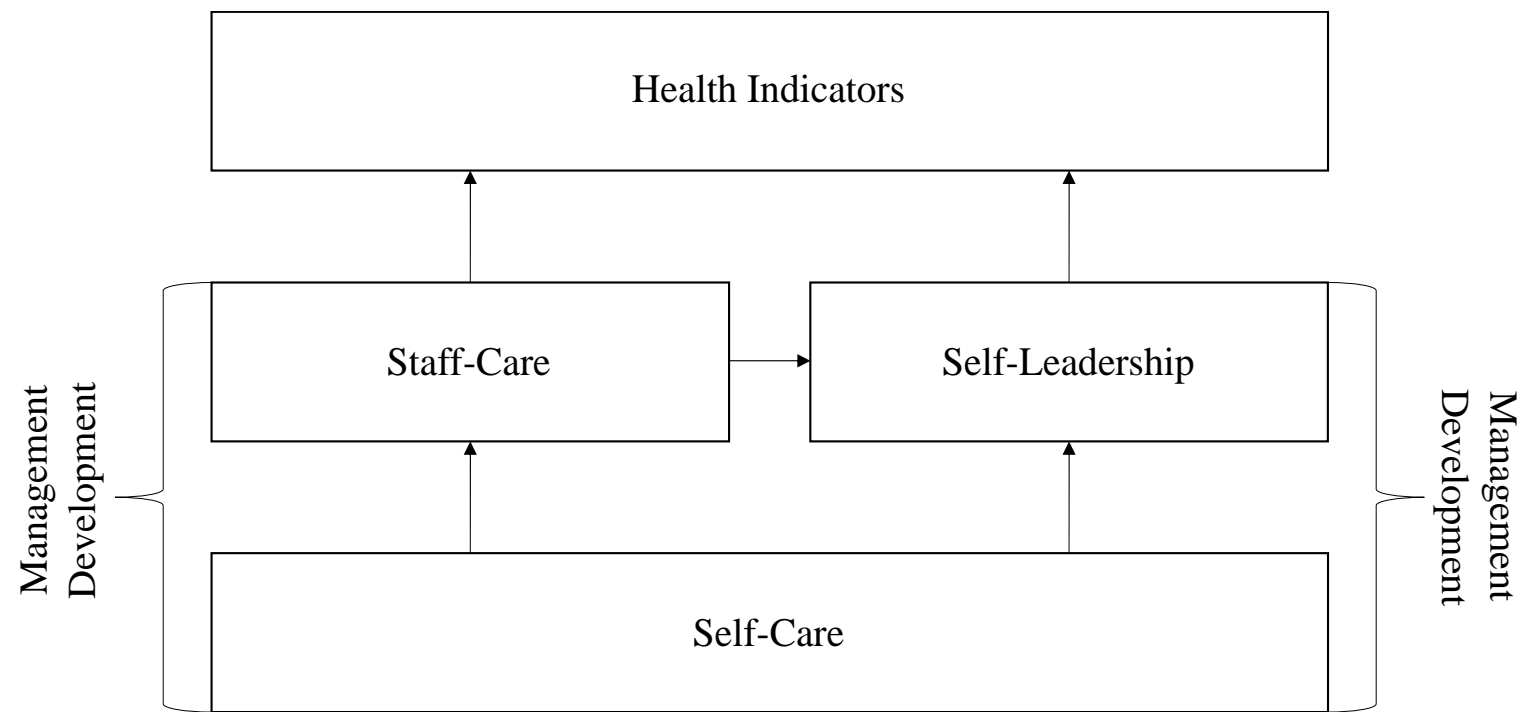

Figure 1. Own Presentation: Levels of Health-Promoting Management

Source: Felfe \& Franke, 2014: 113

In this context, health-promoting management should be expressed in the fact that health indicators (physical complaints, stress, etc.) improve for both employees and managers. According to Franke et al. (2011) Occupational health promotion or health-promoting behavior are typically associated with the following objectives:

Improving job satisfaction and the working atmosphere.

$>$ Health-promoting design of the workplace to reduce stress levels.

$>$ Reduction of absenteeism due to complaints and illnesses.

$>$ Raising awareness of health issues and increasing the knowledge base about health.

$>$ Increased employee motivation, identification and loyalty.

$>$ Optimization of corporate image and competitiveness.

Typically, the measures of health-promoting management go beyond the legal regulations that companies have to fulfill anyway. Legal regulations in Germany that relate to the health protection of employees include, above all, the Working Hours Act and the Occupational Safety Act. According to Tranfield et al. (2003), healthfocused management is understood as an ongoing effort to enable people to create their following positive lives. According to this understanding, the emphasis is on existing resources, which can be strengthened through active management among employees. Among the resources, a change in awareness, as well as active empowerment, should be strengthened. In the view of $\mathrm{Yu}$ et al. (2019), health-oriented management is therefore primarily considered an intangible factor in the interpersonal management context. Based on this proposition, the criteria of health, nutrition and work-life balance were used and focused on this research.

Management Development. Based on the potential of health-oriented management, management development is concerned with the development of training concepts to impart this knowledge (Humphreys, 2001). In this context, it is of interest how the training is methodically designed, which contents are typically imparted and how the training can be evaluated. Regardless of the topic in question, management training is typically geared toward promoting the methodical-strategic, technical or social skills of managers. This is also the case with executive training courses that relate to workplace health promotion. By promoting methodical-strategic skills, it is intended to make it easier for managers to plan health measures strategically and implement them operationally. The training of professional competencies primarily involves imparting health-related expertise to the managers (Branine, 2005). Through the training of social skills, it is intended to make it easier for managers to respond to employees and to convince them of the usefulness of health promotion. With regard to health-oriented management training, a distinction can be made between behavior-related and relationship-related training. In the former, the focus is on the individual health awareness of the managers (Lau \& McLean, 2013). In contrast, relationship-based training focuses more on employees and the company. In this training, the focus is on the health-oriented management of the employees, so that this training has the objective of improving employee health. In the process, the managers are to receive further training about relationship prevention. According to Humphreys (2001), this is understood to mean that the managers preventively design the working conditions in such a way that the health hazards in the company are minimized. The health-oriented executive training can be implemented in the form of company workshops ("on the job"), which are carried out at the 
workplace. Similarly, training can also take place outside the company or workplace ("off the job"). In the case of on-the-job training, managers are taught practical and job-related knowledge. As part of such training, managers often visit different company departments and workplaces to gain an overall view of workplace health issues (Branine, 2005). Characteristic of the method of off-the-job training courses are "classical classroom lectures, programmed instructions (training manuals which allow trainees to adapt the progress to their own pace), simulators (especially for the training of motor skills, and critical situations, e.g., for pilots), and distance learning methods (like online-based courses) (Lau \& McLean, 2013). Regardless of whether the executive training courses are held in-house or externally, they are often aimed at groups. The course instructors often initiate group discussions that are intended to promote both self-reflection and the exchange of experiences among managers. In the form of practical work assignments, the leaders are to be given knowledge on how to integrate the course content into their everyday leadership (Sambrook, 2009).

In principle, numerous management training courses are offered in relation to health promotion. This training is aimed at managers, but possible groups of participants also include personnel developers, personnel managers, company health officers and works councils (Winterton \& Winterton, 1997). The training is designed to enable participants to assume the function of a health manager in their company. Accordingly, the participants are to be enabled to act as contact persons and consultants in the field of health promotion and health protection (Lau \& McLean, 2013). The course content includes teaching the participants to identify health hazards and to be able to react to them adequately. Participants also gain knowledge about which people and institutions need to be involved and how health promotion can be introduced and implemented in the company in an innovative, cost-effective, and efficient manner. The course also includes information on the economic aspects and financial consequences of health-promoting management. The training comprises three workshops or attendance phases, each of which lasts two days. During the last attendance phase, the participants take part in an examination. In the course of this, they work on a realistic, business-related case study in which they are required to develop suitable solutions (Barnett et al., 1996).

\section{Systematic Literature Review}

Based on these theoretical concepts, a systematic literature review was conducted to determine the relevance of health promotion aspects in management development. The literature review for relevant studies was conducted from November 2020 to February 2021 using the following bibliographic databases: Econbiz, EBSCO, Scopus, EBSCO, Google Scholar and Web of Science. The database Econbiz was used as the main database because this database is one of the largest specialized databases on this subject area and is freely accessible. To perform the systematic analysis, various articles published between 2016 to 2020 were evaluated for review. To search for relevant articles on this issue, the following search terms were used on each database. The keywords are leadership, management, work-life balance, health, fitness, food, nutrition, course and training. These terms have been combined in different ways. The terms "course" and "training" are used to ensure that the English-language articles deal with leadership training and continuing education. The terms "leadership" and "management" are used to ensure that the publication refers to leadership training. To capture the concept of health, the terms health and fitness were considered. The terms Food and Nutrition were selected for the area of nutrition. The term work-life balance was placed in quotation marks in the search to ensure that the focus was on work-life balance and that hits were not listed in which the three individual terms work, life and balance appeared separately. Besides, the publication is marked as to which topic is the focus, whether an empirical study was conducted regarding the training measures, and whether the training measures primarily relate to the self-leadership of the managers or primarily to the leadership of employees. Empirical studies that focused on health in the context of leadership development were marked with an H. Studies that examined nutrition as a component in the training design were abbreviated as $\mathrm{N}$, and studies that focused on work-life balance topics were labeled $\mathrm{W}$.

Using the databases Scopus, Econbiz, Web of Science, Google Scholar and EBSCO, the corresponding search term was entered first. In the second step, all relevant listed articles were transferred to Microsoft Excel. Subsequently, all duplicates were removed. Then, all titles and abstracts of the studies were checked for the criteria as well as the method used. The full texts of the studies were reviewed as soon as a decision of the above review criteria could not be made. The results of each step were sorted into a spreadsheet according to the years and listed thematically. In the third step, the information of the included studies was processed and prepared based on the following points: a) author, year of publication, b) title of the article, c) published journal, d) subject field, e) methodology used. As a result of this analysis, out of 56 selected articles on this context, 20 pieces of empirical evidence were elicited that prove the effectiveness of health-oriented elements in 
leadership development. The 20 relevant articles are presented chronologically in Table 1 . The tables show the authors, the title of the publication, and the journal or publisher.

Table 1. Own Presentation: Systematic Literature Review of Empirical Findings to the Relevance of Health Promotion in Management Development

\begin{tabular}{|c|c|c|c|c|}
\hline Author(s) & $\begin{array}{c}\text { Title } \\
\end{array}$ & Journal & Topic & Methodology \\
\hline $\begin{array}{l}\text { Arokiasamy, A. R. A., } \\
\text { Abdullah, A. G. K., Ahmad, M. } \\
\text { Z., \& Ismail, A. (2016) }\end{array}$ & $\begin{array}{c}\text { Transformational leadership of } \\
\text { school principals and organizational } \\
\text { health of primary school teachers in } \\
\text { Malaysia. }\end{array}$ & $\begin{array}{l}\text { Procedia-Social and } \\
\text { Behavioral Sciences }\end{array}$ & $\mathrm{H}$ & $\begin{array}{l}\text { Quantitative } \\
\text { analysis }\end{array}$ \\
\hline $\begin{array}{c}\text { Bronkhorst, B. \& Vermeeren, } \\
\text { B. (2016) }\end{array}$ & $\begin{array}{l}\text { Safety climate, worker health and } \\
\text { organizational health performance: } \\
\text { Testing a physical, psychosocial } \\
\text { and combined pathway. }\end{array}$ & $\begin{array}{l}\text { International Journal of } \\
\text { Workplace Health } \\
\text { Management }\end{array}$ & $\mathrm{H}$ & $\begin{array}{l}\text { Quantitative } \\
\text { analysis }\end{array}$ \\
\hline Lee, Y. M., Sozen, E. (2016) & $\begin{array}{c}\text { Food allergy knowledge and } \\
\text { training among restaurant } \\
\text { employees. }\end{array}$ & $\begin{array}{c}\text { International Journal of } \\
\text { Hospitality } \\
\text { Management }\end{array}$ & $\mathrm{N}$ & $\begin{array}{l}\text { Mixed methods } \\
\text { (qualitative \& } \\
\text { quantitative } \\
\text { analysis) }\end{array}$ \\
\hline $\begin{array}{l}\text { Shipton, H., Sanders, K., } \\
\text { Atkinson, C., \& Frenkel, S. } \\
\text { (2016) }\end{array}$ & $\begin{array}{l}\text { Sense-giving in health care: the } \\
\text { relationship between the HR roles } \\
\text { of line managers and employee } \\
\text { commitment. }\end{array}$ & $\begin{array}{l}\text { Human Resource } \\
\text { Management Journal }\end{array}$ & $\mathrm{H}$ & $\begin{array}{l}\text { Quantitative } \\
\text { analysis }\end{array}$ \\
\hline Ahlers, E. (2017) & $\begin{array}{c}\text { Work and health in German } \\
\text { companies: Findings from the WSI } \\
\text { works councils survey } 2015 .\end{array}$ & $\begin{array}{l}\text { Düsseldorf: Hans- } \\
\text { Böckler-Stiftung. }\end{array}$ & $\mathrm{H}$ & $\begin{array}{l}\text { Quantitative } \\
\text { analysis }\end{array}$ \\
\hline $\begin{array}{c}\text { Apipalakul, C., \& Kummoon, } \\
\text { D. (2017) }\end{array}$ & $\begin{array}{l}\text { The effects of organizational } \\
\text { climate to conflict management } \\
\text { amongst organizational health } \\
\text { personnel. }\end{array}$ & $\begin{array}{l}\text { Procedia-Social and } \\
\text { Behavioral Sciences }\end{array}$ & $\mathrm{H}$ & $\begin{array}{l}\text { Quantitative } \\
\text { analysis }\end{array}$ \\
\hline $\begin{array}{l}\text { Busch, C., Koch, T., Clasen, J., } \\
\text { Winkler, E., \& Vowinkel, J. } \\
\text { (2017) }\end{array}$ & $\begin{array}{l}\text { Evaluation of an organizational } \\
\text { health intervention for low-skilled } \\
\text { workers and im- migrants. }\end{array}$ & Human Relations & $\mathrm{H}$ & $\begin{array}{l}\text { Quantitative } \\
\text { analysis }\end{array}$ \\
\hline $\begin{array}{c}\text { Dunsch, F., Evans, D., Eze- } \\
\text { Ajoku, E. \& Macis, M. (2017) }\end{array}$ & $\begin{array}{l}\text { Management, supervision, and } \\
\text { health care. A field experiment. }\end{array}$ & $\begin{array}{l}\text { Forschungsinstitut zur } \\
\text { Zukunft der Arbeit. }\end{array}$ & $\mathrm{H}$ & $\begin{array}{l}\text { Quantitative } \\
\text { analysis }\end{array}$ \\
\hline $\begin{array}{l}\text { Schultz, J., Sjøvold, E. \& } \\
\text { André, B. (2017) }\end{array}$ & $\begin{array}{c}\text { Can formal innovation training } \\
\text { improve group- and organizational- } \\
\text { level innovativeness in a healthcare } \\
\text { setting? }\end{array}$ & $\begin{array}{l}\text { Journal of innovation } \\
\text { and entrepreneurship }\end{array}$ & $\mathrm{H}$ & $\begin{array}{l}\text { Mixed methods } \\
\text { (qualitative \& } \\
\text { quantitative } \\
\text { analysis) }\end{array}$ \\
\hline $\begin{array}{l}\text { Röttger, S., Maier, J., Krex- } \\
\text { Brinkmann, L., Kowalski, J. T., } \\
\text { Krick, A., Felfe, J., \& Stein, M. } \\
\text { (2017) }\end{array}$ & $\begin{array}{l}\text { Social cognitive aspects of the } \\
\text { participation in workplace health } \\
\text { promotion as revealed by the theory } \\
\text { of planned behavior. }\end{array}$ & Preventive medicine & $\mathrm{H}$ & $\begin{array}{l}\text { Quantitative } \\
\text { analysis }\end{array}$ \\
\hline $\begin{array}{l}\text { Hopkins, J., Fassiotto, M., Ku, } \\
\text { M. C., Mammo, D, \& } \\
\text { Valantine, H. (2018) }\end{array}$ & $\begin{array}{l}\text { Designing a Physician Leadership } \\
\text { Development Program Based on } \\
\text { Effective Models of Physician } \\
\text { Education. Health care management } \\
\text { review. }\end{array}$ & $\begin{array}{c}\text { Health care } \\
\text { management review }\end{array}$ & $\mathrm{H}$ & $\begin{array}{l}\text { Quantitative } \\
\text { analysis }\end{array}$ \\
\hline James, E. \& Zoller, H. (2018) & $\begin{array}{l}\text { Resistance training. (Re)shaping } \\
\text { extreme forms of workplace health } \\
\text { promotion. }\end{array}$ & $\begin{array}{l}\text { Management } \\
\text { communication } \\
\text { quarterly }\end{array}$ & $\mathrm{H}$ & $\begin{array}{l}\text { Qualitative } \\
\text { Analysis }\end{array}$ \\
\hline $\begin{array}{l}\text { Ogbonnaya, C., Tillman, J, \& } \\
\text { Gonzalez, K, (2019) }\end{array}$ & $\begin{array}{l}\text { Perceived organizational support in } \\
\text { health care. The importance of } \\
\text { teamwork and training for } \\
\text { employee wellbeing and patient } \\
\text { satisfaction. }\end{array}$ & $\begin{array}{l}\text { Group \& organization } \\
\text { management: an } \\
\text { international journal }\end{array}$ & $\mathrm{H}$ & $\begin{array}{l}\text { Mixed methods } \\
\text { (qualitative \& } \\
\text { quantitative } \\
\text { analysis) }\end{array}$ \\
\hline $\begin{array}{c}\text { Ayeleke, R., North, N., } \\
\text { Dunham, A. \& Wallis A. (2019) }\end{array}$ & $\begin{array}{l}\text { Impact of training and professional } \\
\text { development on health management } \\
\text { and leadership competence. }\end{array}$ & $\begin{array}{l}\text { Journal of Health } \\
\text { Organization and } \\
\text { Management }\end{array}$ & $\mathrm{H}$ & $\begin{array}{l}\text { Quantitative } \\
\text { analysis }\end{array}$ \\
\hline $\begin{array}{l}\text { Einarsen, K., Salin, D., } \\
\text { Einarsen, S., Skogstad, A. \& } \\
\text { Mykletun, R. (2019) }\end{array}$ & $\begin{array}{l}\text { Antecedents of ethical infra- } \\
\text { structures against workplace } \\
\text { bullying. The role of organizational } \\
\text { size, perceived financial resources, } \\
\text { and level of high-quality HRM } \\
\text { practices. }\end{array}$ & Personnel Review & $\mathrm{W}$ & $\begin{array}{l}\text { Quantitative } \\
\text { analysis }\end{array}$ \\
\hline $\begin{array}{l}\text { Yu, H., Sirsat, S., Neal, J. } \\
\text { (2019) }\end{array}$ & $\begin{array}{l}\text { Linking food safety training with } \\
\text { whistleblowing. The mediation } \\
\text { roles of job satisfaction and self- } \\
\text { efficacy. }\end{array}$ & $\begin{array}{c}\text { International Journal of } \\
\text { Contemporary } \\
\text { Hospitality } \\
\text { Management }\end{array}$ & $\mathrm{N}$ & $\begin{array}{l}\text { Quantitative } \\
\text { analysis }\end{array}$ \\
\hline
\end{tabular}


Table 2 (cont.). Own Presentation: Systematic Literature Review of Empirical Findings to the Relevance of Health Promotion in Management Development

\begin{tabular}{|c|c|c|c|c|}
\hline $\begin{array}{c}\text { Freire, C. \& Bettencourt, C. } \\
\text { (2020) }\end{array}$ & $\begin{array}{c}\text { Impact of ethical leadership on job } \\
\text { satisfaction. The mediating effect of } \\
\text { work-family conflict. }\end{array}$ & $\begin{array}{c}\text { Leadership \& } \\
\text { Organization } \\
\text { Development Journal }\end{array}$ & W & $\begin{array}{c}\text { Quantitative } \\
\text { analysis }\end{array}$ \\
\hline $\begin{array}{c}\text { Johnson, K. R., Park, S., \& } \\
\text { Chaudhuri, S. (2020) }\end{array}$ & $\begin{array}{c}\text { Mindfulness training in the } \\
\text { workplace: exploring its scope and } \\
\text { outcomes. }\end{array}$ & $\begin{array}{c}\text { European Journal of } \\
\text { Training and } \\
\text { Development. }\end{array}$ & $\begin{array}{c}\text { Mixed methods } \\
\text { (qualitative \& } \\
\text { quantitative } \\
\text { analysis) }\end{array}$ \\
\hline $\begin{array}{c}\text { Rattrie, L. \& Kittler, M. (2020) } \\
\text { Ill-being or well-being? Energizing } \\
\text { international business travelers. } \\
\text { Organizational } \\
\text { Eualitative } \\
\text { Analysis } \\
\text { and Performance }\end{array}$ & H & $\begin{array}{c}\text { Jhe International } \\
\text { Journal of Human } \\
\text { Resource Management }\end{array}$ & H & $\begin{array}{c}\text { Quantitative } \\
\text { analysis }\end{array}$ \\
\hline $\begin{array}{c}\text { Ybema, J. F., van Vuuren, T., \& } \\
\text { van Dam, K. (2020) }\end{array}$ & $\begin{array}{c}\text { HR practices for enhancing } \\
\text { sustainable employability: } \\
\text { implementation, use, and outcomes. }\end{array}$ \\
\hline
\end{tabular}

Source: Wells et. al., 2003: 202-206

\section{Discussion}

The effectiveness of health-related executive training can be considered high in that many publications on health-promoting leadership emphasize the importance of executive training. In 2017, five relevant publications were identified. Three of these publications made a connection between management training and health issues from an organizational perspective. While two articles focused on leadership training that deals with work-life balance, no publication dealt with nutrition-related leadership training this year. In 2018, two relevant publications were related to health-focused leadership training with a focus on the workplace and satisfaction. For 2019, two of the eleven publications researched addressed leadership training in work-life balance, whereas one article addressed nutrition-related leadership training. The literature search for the year 2020 revealed especially that new work concepts about work-life balance become relevant from a management perspective.

The literature analysis has also shown that there is a wide variety of training regarding health, nutrition, and work-life balance, in which different methods are used. Particularly due to the depth and complexity of these topics, it can be considered indisputable that supervisors need specific training measures for health-oriented leadership. Because the potential benefits of health-promoting management can hardly be questioned, it tends to be assumed that this leadership approach is not some kind of fad that will be replaced by other leadership and management approaches in the future. The health-oriented leadership training courses, which can be conducted internally or externally, are usually aimed at groups, although individual training courses, especially in the form of coaching, are also possible in principle. Furthermore, it became clear that many health-related training measures are not specifically designed for executives. At the very least, these training programs, as described above, address a broad target group that also includes people who do not have management responsibilities. In the meantime, digital methods have also found their way into health-related management training, so that e-learning or blended learning training courses are offered. In the comments on management training, it is considered essential that supervisors address their health, work-life balance, or nutrition.

This is considered important because supervisors can act as role models. Self-reflection is also seen as a key mechanism for supervisors to communicate training content to their employees in a professionally functional and persuasive manner. Few sources could be researched that indicate that leadership training is limited to selfleadership. One course content that is essential for health-promoting leadership is communication with employees. Here, the focus is not only on conveying technical information but also on empathic, active listening, which is particularly significant in terms of detecting indications of mental illness among employees. In this context, it is obvious that managers do not have the function of making medical diagnoses and naming specific clinical pictures. Rather, it seems important for managers to be able to recognize that employees are suffering from mental stress and to suggest or offer suitable further assistance.

\section{Implications \& Recommendation}

Even though a total of 56 sources could be researched for the period from January 2016 to November 2020, an existing need for research could be identified to explore further economic potentials of health aspects in management programs of companies. Nevertheless, it remains to be noted that since 2016, health-promoting aspects in management training have also been gaining importance from a scientific perspective. As shown in the previous studies, health-promoting measures can make a positive contribution to health in the organization. 
However, there are apparently few current studies that examine the importance of the training about the respective training content and methods. It could also be interesting to evaluate health-promoting aspects in the leadership style of the management in more detail. Surveys in this regard usually use only a quantitative research approach with predefined response categories (too few resources, lack of management support, lack of know-how, etc.). However, a qualitative research design in which expert interviews are conducted with managers could also be informative. This type of survey could be used to examine in greater detail the attitudes and reasons on the part of supervisors that block or impede the implementation of health-promoting leadership. It cannot be ruled out that many supervisors believe that nutrition is a personal matter in which the employer should not interfere. Particularly among older and more traditional managers, there could also be the prejudice that promoting the work-life balance at the employee level leads to a reduction in the willingness to make an unconditional commitment to the company (for example, working overtime or being constantly available during free time).

It is reasonable to assume that the importance of health-oriented management in companies will continue to increase in the future. The impression can be gained that employees are increasingly placing idealistic demands on a workplace, which is reflected, for example, in the appreciation of a work-life balance. Companies can therefore increase their attractiveness as employers by implementing a company health management system and offering various health measures. Within the business management literature, the prevailing view is that health-promoting management has a real or monetary benefit for companies. At the same time, the assumption seems to be obvious that the benefit differs from company to company and thus every organization is faced with the task of evaluating the benefit of health-oriented management, especially using key figures. It can be considered essential that workplace health promotion is driven and implemented by managers. In this context, it can be assumed that numerous superiors had only relatively superficial contact with topics such as health, nutrition and work-life balance during their training and professional careers. However, it seems necessary for supervisors to have a profound knowledge of these topics that goes beyond general education to implement health-oriented management. Therefore, health- and nutrition-related leadership training can be seen as goaloriented. It can also be considered important that the company management makes it clear to the (middle and lower) managers that health promotion is part of modern management approaches and that topics such as nutrition and work-life balance are now part of the everyday life of managers. In terms of leadership training, it is likely to be beneficial if different leaders specialize in certain topics related to health, nutrition and worklife balance. If different leaders align on different topics, it seems more feasible for companies to offer a wide range of measures and expertise to their employees. The literature review shows that there is still considerable room for improvement in the implementation of health-promoting leadership. Above all, it would be desirable if even more companies were prepared to set up health-oriented leadership or occupational health management.

\section{Acknowledgement}

The author would like to thank the two anonymous reviewers for reading, reflecting, evaluating and constructively commenting, which contributed significantly to the finalisation of this study. Furthermore I would like to thank ARMG Publishing and the scientists involved for the possibility of publication and the appreciative cooperation.

Funding. There is no funding for this research.

\section{References}

1. Ahlers, E. (2017). Work and health in German companies: Findings from the WSI works councils survey 2015 (No. 33e). WSI Report. https://www.econstor.eu/handle/10419/225393. Accessed January 2021.

2. Apipalakul, C., \& Kummoon, D. (2017). The effects of organizational climate to conflict management amongst organizational health personnel. Procedia-Social and Behavioral Sciences, 237, 1216-1222. https://doi.org/10.1016/j.sbspro.2017.02.192.

3. Arokiasamy, A.R.A., Abdullah, A.G.K., Ahmad, M.Z., \& Ismail, A. (2016). Transformational leadership of school principals and organizational health of primary school teachers in Malaysia. Procedia-Social and Behavioral Sciences, 229, 151-157. https://doi.org/10.1016/j.sbspro.2016.07.124.

4. Busch, C., Koch, T., Clasen, J., Winkler, E., \& Vowinkel, J. (2017). Evaluation of an organizational health intervention for low-skilled workers and immigrants. Human Relations, 70(8), 994-1016. https://doi.org/10.1177/0018726716682308.

5. Ayeleke, R.O., North, N.H., Dunham, A., \& Wallis, K.A. (2019). Impact of training and professional development on health management and leadership competence. Journal of health organization and management, 33(4), 354-379. https://doi.org/10.1108/JHOM-11-2018-0338. 
6. Ogbonnaya, C., \& Babalola, M.T. (2019). A closer look at how managerial support can help improve patient experience: Insights from the UK's National Health Service. Human Relations, 1-20. https://doi.org/10.1177/0018726720938834.

7. Freire, C., \& Bettencourt, C. (2020). Impact of ethical leadership on job satisfaction: the mediating effect of work-family conflict. Leadership \& Organization Development Journal, 41(2), 319-330. https://doi.org/10.1108/LODJ-07-2019-0338.

8. Esslinger, A.S., Emmert, M., \& Schöffski, O. (2010). Betriebliches Gesundheitsmanagement: mit gesunden Mitarbeitern zu unternehmerischem Erfolg. [Occupational health management: With healthy employees to entrepreneurial success]. Springer-Verlag, 69-70. https://link.springer.com/chapter/10.1007/978-3-66258314-2_67. Accessed Januar 2021.

9. Rattrie, L., \& Kitter, M. (2020). Ill-being or well-being? Energising international business travellers. Journal of Organizational Effectiveness: People and Performance, 7(2), 117-137. https://doi.org/10.1108/JOEPP-02-2019-0011.

10.James, E.P., \& Zoller, H.M. (2018). Resistance training:(Re) shaping extreme forms of workplace health promotion. Management Communication Quarterly, 32(1), 60-89. https://doi.org/10.1177/0893318917696990.

11.Einarsen, K., Salin, D., Einarsen, S.V., Skogstad, A., \& Mykletun, R.J. (2019). Antecedents of ethical infrastructures against workplace bullying. Personnel Review, 48(3), 672-690. https://doi.org/10.1108/PR10-2017-0303.

12.Car, L.T., Kyaw, B.M., \& Atun, R. (2018). The role of eLearning in health management and leadership capacity building in health system: a systematic review. Human resources for health, 16(1), 1-9. https://doi.org/10.1186/s12960-018-0305-9.

13.Johnson, K.R., Park, S., \& Chaudhuri, S. (2020). Mindfulness training in the workplace: exploring its scope and outcomes. European Journal of Training and Development, 44(4/5), 341-354. https://doi.org/10.1108/EJTD-09-2019-0156.

14.Seel, M., \& Hurling, E. (2005). Die Pflege des Menschen im Alter [The people care in old age]. Auflage, Schlütersche, Hannover, 35-40. Available at: https://content-select.com/de/portal/media/view/58984482685c-4b94-9397-47f1b0dd2d03.

15.Hopkins, Joseph, Fassiotto, Magali, Ku, Manwai Candy, Mammo, Dagem \& Valantine, Hannah (2018). Designing a Physician Leadership Development Program Based on Effective Models of Physician Education. Health care management review, 43(4), 293-302. https://doi.org/10.1097/HMR.0000000000000146.

16.Dunsch, F.A., Evans, D.K., Eze-Ajoku, E., \& Macis, M. (2017). Management, supervision, and health care: a field experiment. National Bureau of Economic Research, № 23749, 2-20. https://doi.org/10.3386/w23749.

17.Lee, Y.M., Sozen, E. (2016). Food allergy knowledge and training among restaurant employees. International Journal of Hospitality Management, 57, 52-59. https://doi.org/10.1016/j.ijhm.2016.05.004.

18.Felfe, J., \& Franke, F. (2014). Führungskräftetrainings [Management training]. Hogrefe Verlag. Available at: https://pubengine2.s3.eu-central-1.amazonaws.com/preview/99.110005/9783840923883_preview.pdf.

19.Franke, F., Vincent, S., \& Felfe, J. (2011). Gesundheitsbezogene Führung [Healthoriented Leadership]. In Gesundheitsförderung und Gesundheitsmanagement in der Arbeitswelt (pp. 371-392). Ein Handbuch. Göttingen: Hogrefe. Available at: https://link.springer.com/chapter/10.1007/978-3-642-21655-8_1.

20.Tranfield, D., Denyer D. \& Smart, P. (2003). Towards a Methodology for Developing Evidence-Informed Management Knowledge by Means of Systematic Review. British Journal of Management, 14(3), 207-222. https://doi.org/10.1111/1467-8551.00375.

21.Yu, H., Sirsat, S., Neal, J. (2019). Linking food safety training with whistle- blowing: The mediation roles of job satisfaction and self-efficacy. International Journal of Contemporary Hospitality Management, 31(1), 141-160. https://doi.org/10.1108/IJCHM-10-2017-0689.

22.Schultz, J.S., Sjøvold, E., \& André, B. (2017). Can formal innovation training improve group-and organizational-level innovativeness in a healthcare setting? Journal of Innovation and Entrepreneurship, 6(1), 1-21. https://doi.org/10.1186/s13731-017-0073-0.

23.Shanafelt, T.D., \& Noseworthy, J.H. (2017). Executive leadership and physician well-being: nine organizational strategies to promote engagement and reduce burnout. Mayo Clinic Proceedings, 92(1), 129-146. https://doi.org/10.1016/j.mayocp.2016.10.004.

24.Röttger, S., Maier, J., Krex-Brinkmann, L., Kowalski, J.T., Krick, A., Felfe, J., \& Stein, M. (2017). Social cognitive aspects of the participation in workplace health promotion as revealed by the theory of planned behavior. Preventive medicine, 105, 104-108. https://doi.org/10.1016/j.ypmed.2017.09.004. 
25.Shipton, H., Sanders, K., Atkinson, C., \& Frenkel, S. (2016). Sense-giving in health care: the relationship between the HR roles of line managers and employee commitment. Human Resource Management Journal, 26(1), 29-45. https://doi.org/10.1111/1748-8583.12087.

26.Humphreys, P. (2001). Designing a management development programme for procurement executives. Journal of management development, 20(7), 604-623. https://doi.org/10.1108/EUM0000000005635.

27.Branine, M. (2005). Cross-cultural training of managers: An evaluation of a management development programme for Chinese managers. Journal of Management Development, 24(5), 459-472. https://doi.org/10.1108/02621710510598463.

28.Lau, P.Y.Y., \& McLean, G.N. (2013). Factors influencing perceived learning transfer of an outdoor management development programme in Malaysia. Human Resource Development International, 16(2), 186-204. https://doi.org/10.1080/13678868.2012.756157.

29.Sambrook, S. (2009). Critical pedagogy in a health service management development programme: Can critically thinking" managers change the NHS management culture? Journal of Health Organization and Management, 23(6), 656-671. https://doi.org/10.1108/14777260911001662.

30.Winterton, J., \& Winterton, R. (1997). Does management development add value? British Journal of Management, 8, 65-76. https://doi.org/10.1111/1467-8551.8.s1.6.

31.Barnett, S., Patrickson, M., \& Maddern, J. (1996). Negotiating the evolution of the HR function: practical advice from the health care sector. Human Resource Management Journal, 6(4), 18-37. https://doi.org/10.1111/j.1748-8583.1996.tb00416.x.

32.James, E.P., \& Zoller, H.M. (2018). Resistance training:(Re)shaping extreme forms of workplace health promotion. Management Communication Quarterly, 32(1), 60-89. https://doi.org/10.1177/0893318917696990.

33. Ybema, J. F., van Vuuren, T., \& van Dam, K. (2020). HR practices for enhancing sustainable employability: implementation, use, and outcomes. The International Journal of Human Resource Management, 31(7), 886-907. https://doi.org/10.1080/09585192.2017.1387865.

34.Bronkhorst, B., \& Vermeeren, B. (2016). Safety climate, worker health and organizational health performance: Testing a physical, psychosocial and combined pathway. International Journal of Workplace Health Management, 9(3), 270-289. https://doi.org/10.1108/IJWHM-12-2015-0081.

35.Wells, J., Barlow, J., \& Stewart-Brown, S. (2003). A systematic review of universal approaches to mental health promotion in schools. Health Education, 103(4), 197-220. https://doi.org/10.1108/09654280310485546. 